\title{
PERBEDAAN HASIL BELAJAR MATEMATIKA PADA PENERAPAN MODEL PEMBELAJARAN DISCOVERY LEARNING DENGAN MODEL PEMBELAJARAN INQUIRY
}

\author{
Petra C. M. Sumampou ${ }^{1)}$, Dasa Ismaimuza ${ }^{2)}$ dan Ibnu Hadjar ${ }^{3)}$ \\ sumampoupetra@gmail.com ${ }^{1)}$,dasaismaimuza@gmail.org.uk ${ }^{2}$, \\ ibnuhadjar67@gmail.com ${ }^{3)}$
}

\begin{abstract}
Abstrak: Tujuan penelitian ini adalah untuk mengkaji dan menganalisis perbedaan hasil belajar matematika antara siswa yang belajar menggunakan model pembelajaran discovery learning dengan siswa yang belajar menggunakan model pembelajaran inquiry di kelas $\mathrm{X}$ SMA Negeri 2 Palu, baik secara keseluruhan, antara siswa berkemampuan tinggi, antara siswa berkemampuan sedang dan antara siswa berkemampuan rendah. Hipotesis yang diajukan dalam penelitian ini yaitu terdapat perbedaan hasil belajar matematika antara siswa yang belajar menggunakan model pembelajaran discovery learning dengan siswa yang belajar menggunakan model pembelajaran inquiry di kelas X SMA Negeri 2 Palu, baik secara keseluruhan, antara siswa berkemampuan tinggi, antara siswa berkemampuan sedang dan antara siswa berkemampuan rendah. Subjek penelitian berjumlah 72 siswa yang terdiri dari 36 siswa kelas X MIA 3 sebagai kelas yang belajar menggunakan model pembelajaran inquiry dan 36 siswa kelas X MIA 5 yang belajar menggunakan model pembelajaran discovery learning. Materi yang dipelajari oleh siswa yaitu Sistem Persamaan Linear Tiga Variabel, Relasi dan Fungsi. Berdasarkan hasil perhitungan uji hipotesis untuk $\alpha=0,05$ diperoleh $\mathrm{p}>\alpha$ untuk semua hipotesis, sehingga $\mathrm{H}_{1}$ ditolak dan $\mathrm{H}_{0}$ diterima untuk semua hipotesis. Dapat disimpulkan bahwa tidak terdapat perbedaan hasil belajar matematika antara siswa yang belajar menggunakan model pembelajaran discovery learning dengan siswa yang belajar menggunakan model pembelajaran inquiry di kelas $\mathrm{X}$ SMA Negeri 2 Palu, baik secara keseluruhan, antara siswa berkemampuan tinggi, antara siswa berkemampuan sedang dan antara siswa berkemampuan rendah.
\end{abstract}

Kata Kunci : perbedaan, hasil belajar, discovery learning, inquiry, sistem persamaan linear tiga variabel, relasi dan fungsi.

Pembelajaran matematika tidak hanya menuntut siswa untuk menghafal rumusrumus tetapi juga menuntut siswa untuk memahami konsep matematika. Cara untuk mengetahui seberapa besar penguasaan materi siswa dapat dilihat dari hasil belajar matematika yang diperolehnya. Pada kenyataannya tidak semua siswa dapat menguasai materi pelajaran dengan baik sehingga membuat hasil belajar siswa tidak maksimal. Hal ini disebabkan oleh rendahnya pemahaman konsep yang dimiliki siswa karena siswa tidak mencari dan memecahkan masalah yang dihadapinya (Palupi, $2013: 1$ ).

Penguasaan materi pelajaran matematika dengan baik sangat mempengaruhi hasil belajar matematika siswa. Penguasaan materi tidak dapat dilakukan hanya dengan menghafal rumus dan mengerjakan soal-soal latihan, melainkan siswa perlu untuk menemukan sendiri konsep dari suatu materi pelajaran sehingga pengetahuan yang dimiliki siswa akan bertahan lebih lama. Proses pembelajaran akan mempengaruhi penguasaan materi oleh siswa, sehingga guru perlu memilih model pembelajaran yang dapat mengarahkan siswa untuk berperan aktif dalam proses pembelajaran. Model pembelajaran yang digunakan hendaknya dapat membuat siswa menemukan sendiri konsep dari materi yang akan dipelajari.

Kosasih (2013:83-84) menyatakan bahwa model pembelajaran discovery learning dapat mengarahkan siswa untuk menemukan sesuatu melalui proses pembelajaran yang dilakoninya dimana siswa tidak hanya sebagai konsumen, tetapi diharapkan bisa berperan aktif, bahkan sebagai pelaku pencipta ilmu pengetahuan. Bentuk penemuan yang dimaksud 
tidak selalu identik dengan teori ataupun benda sebagaimana yang biasa dilakukan kalangan ilmuwan professional dalam pengertian yang sebenarnya. Penemuan yang dimaksud berarti pula penemuan yang sederhana namun memiliki makna dengan kehidupan para siswa itu sendiri.

Maryam (2016:16-17) menyatakan bahwa dalam mengaplikasikan model pembelajaran discovery learning, guru berperan sebagai pembimbing dengan memberikan kesempatan kepada siswa untuk belajar secara aktif. Kondisi seperti ini ingin merubah kegiatan belajar mengajar dari teacher oriented menjadi student oriented. Pembelajaran discovery learning menghendaki guru untuk dapat memberikan kesempatan kepada muridnya untuk menjadi seorang problem solver, seorang saintis, historin atau ahli matematika. Bahan ajar yang diberikan kepada siswa tidak dalam bentuk akhir, siwa dituntut untuk melakukan berbagai kegiatan yaitu menghimpun informasi, membandingkan, mengkategorikan, mengintegrasikan, mengorganisasikan bahan serta membuat kesimpulan-kesimpulan.

Hamruni (2012:88) menyatakan inquiry merupakan rancangan kegiatan pembelajaran yang menekankan pada proses berpikir secara kritis dan analitis untuk mencari dan menemukan sendiri jawaban dari suatu masalah yang dipertanyakan. Artinya model inquiry merupakan model pembelajaran yang menekankan pada pengembangan keterampilan berpikir siswa melalui proses penyelidikan dan penemuan secara mandiri.

Hamiyah (2014:185) menyatakan bahwa model pembelajaran inquiry merupakan model pembelajaran yang bertujuan untuk membantu siswa menemukan cara untuk meningkatkan kemampuan berpikirnya. Model pembelajaran inquiry menuntun siswa mengembangkan cara-cara berpikir reflektif dalam hal ini adalah kemampuan berpikir ilmiah. Model pembelajaran inquiry merupakan pembelajaran yang dikembangkan agar siswa menjadikan kemampuan berpikir ilmiah sebagai dasar dalam memecahan masalah. Pemecahan masalah menuntut siswa untuk mampu menggali dan mencermati secara kritis suatu permasalahan yang dihadapi. Pembelajaran inquiry juga membantu siswa menerapkan kemampuan-kemampuan berpikir ilmiah dalam membandingkan dan memecahkan suatu permasalahan.

Hasil-hasil penelitian di atas menggambarkan bahwa model pembelajaran discovery learning dan model pembelajaran inquiry dapat mengarahkan siswa untuk menemukan sendiri konsep dari suatu materi melalui eksperimen. Beberapa peneliti yang telah melakukan penelitian mengenai kedua model tersebut juga memberi kesimpulan bahwa kedua model ini dapat mempengaruhi kemampuan siswa dalam pemecahan masalah matematika serta lebih efektif dibandingkan dengan model pembelajaran konvensional.

Model pembelajaran discovery learning mirip dengan model pembelajaran inquiry yaitu menekankan pada keaktifan siswa dan pencarian sendiri oleh siswa. Siswa dituntut untuk menemukan sendiri pemecahan dari suatu masalah dengan cara melakukan eksperimen. Fakta ini membuat peneliti ingin melakukan penelitian untuk mengkaji perbedaan hasil belajar matematika antara siswa yang menggunakan model pembelajaran discovery learning dengan yang menggunakan model pembelajaran inquiry.

\section{METODE PENELITIAN}

Jenis penelitian ini merupakan peneltian kuantitatif karena data yang diolah berupa nilai-nilai atau angka-angka dengan perhitungan statistik untuk mengetahui perbedaan hasil belajar matematika siswa antara penerapan model pembelajaran discovery learning dengan 
model pembelajaran inquiry. Melalui hasil pre-test, ditentukan dua kelas yang dijadikan subjek penelitian yaitu kelas X MIA 5 sebagai kelas eksperimen I yang diberi penerapan model pembelajaran discovery learning dan kelas X MIA 3 sebagai kelas eksperimen II yang diberi penerapan model pembelajaran inquiry. Melalui hasil pre-test juga peneliti mengelompokan siswa ke dalam kelompok siswa berkemampuan tinggi, sedang dan rendah.

Penelitian ini menggunakan teknik pengumpulan data berupa tes untuk mengukur hasil belajar siswa, baik yang belajar menggunakan model pembelajaran discovery learning maupun inquiry. Tes ini diberikan pada saat post-test yaitu setelah diberikan perlakuan terhadap kedua kelas eksperimen.

Apabila instrumen berbentuk tes, maka pengujian validitas dapat dilakukan dengan membandingkan isi instrumen dengan materi pelajaran yang telah diajarkan. Sugiyono (2012:129) menyatakan bahwa untuk menguji validitas butir-butir instrumen lebih lanjut perlu dikonsultasikan dengan ahli untuk selanjutnya diujicobakan dan dianalisis dengan analisis item. Analisis item dilakukan dengan menghitung korelasi antara skor butir instrumen dengan skor total menggunakan rumus koefisien korelasi, sedangkan untuk menguji reliabilitas digunakan rumus Spearman Brown.

Analisis data pada penelitian ini dibagi menjadi dua tahap yaitu analisis awal yang mencakup uji normalitas dan homogenitas data serta analasis akhir yang mencakup uji hipotesis. Uji normalitas data menggunakan uji Chi Kuadrat dengan taraf siginfikansi 0,05, sedangkan uji homogenitas data menggunakan uji F. Pengujian hipotesis menggunakan uji $\mathrm{Z}$ apabila data berdistribusi normal, tetapi jika data tidak berdistribusi normal maka pengujian hipotesis menggunakan uji Mann-Whitney.

\section{HASIL PENELITIAN}

Uji validitas dilakukan dengan cara uji ahli dan analisis item dengan cara menghitung nilai korelasi antara skor butir instrumen dengan skor total. Setelah dilakukan perhitungan uji validitas, diperoleh nilai korelasi untuk soal nomor 1 sebesar 0,334 , nilai korelasi untuk soal nomor 2 sebesar 0,694, nilai korelasi untuk soal nomor 3 sebesar 0,887, nilai korelasi untuk soal nomor 4 sebesar 0,626, nilai korelasi untuk soal nomor 5 sebesar 0,484 dan nilai korelasi untuk soal nomor 6 sebesar 0,628. Hal ini menunjukan bahwa semua nilai korelasi di atas 0,3 sehingga dapat disimpulkan bahwa semua butir soal posttest valid. Uji reliabilitas dengan menggunakan rumus Spearman Brown mengasilkan nilai korelasi sebesar 0,968 yang berarti bahwa butir soal reliabel.

Proses pembelajaran dengan model pembelajaran inquiry dan discovery learning dilakukan sebanyak tiga pertemuan pada materi SPLTV, relasi dan fungsi. Siswa berhasil untuk menemukan sendiri konsep dari materi yang dipelajari dan dapat mengaplikasikannya dalam mengerjakan soal latihan yang diberikan pada setiap pertemuan. Hal ini menunjukan bahwa model pembelajaran inquiry dan discovery learning diterapkan dengan baik pada dua kelas eksperimen. Setelah peneliti menerapkan dua perlakuan yaitu model pembelajaran inquiry pada kelas X MIA 3 dan model pembelajaran discovery learning pada kelas X MIA 5, selanjutnya peneliti memberikan post-test sebagai instrumen untuk mengukur hasil belajar siswa. Pemberian post-test di kelas eksperimen I hanya diikuti oleh 32 siswa, sedangkan di kelas eksperimen II ada 36 orang siswa yang mengikuti tes. Hasil post-test menunjukan bahwa rata-rata nilai yang diperoleh kelas eksperimen I sebesar 27,65 dan rata-rata nilai yang diperoleh kelas eksperimen II sebesar 38,77.

Hasil yang diperoleh setelah melakukan perhitungan terhadap data $\chi^{2}$ hitung sebesar 93,3 untuk kelas eksperimen I dan 130,85 untuk kelas eksperimen II, sedangkan nilai dari 
$\chi_{\text {tabel }}^{2}$ sebesar 7,81 atau $\chi_{\text {hitung }}^{2}>\chi_{\text {tabel }}^{2}$ sehingga dapat disimpulkan bahwa data tersebut tidak berdistribusi normal. Uji homogenitas data dilakukan untuk mengetahui bahwa data dari subjek penelitian yang diambil bersifat homogen. Pengujian homogenitas pada penelitian ini dilakukan terhadap kedua kelas eksperimen secara keseluruhan, siswa berkemampuan sedang dan siswa berkemampuan rendah pada masing-masing kelas eksperimen, uji homogenitas tidak dilakukan terhadap siswa berkemampuan tinggi karena ukuran sampel sangat kecil. Berdasarkan hasil perhitungan, diperoleh nilai dari $F_{\text {tabel }}$ untuk kedua kelas eksperimen dengan taraf signifikasi 0,05 , derajat kebebasan pembilang 31 dan derajat kebebasan penyebut 35 adalah 1,8, atau $\mathrm{F}_{\text {hitung }}<\mathrm{F}_{\text {tabel }}$, sehingga dapat disimpulkan bahwa data bersifat homogen. Uji homogenitas untuk kelompok siswa berkemampuan sedang, diperoleh nilai dari $\mathrm{F}_{\text {tabel }}$ dengan taraf signifikasi 0,05 , derajat kebebasan pembilang 6 dan derajat kebebasan penyebut 3 adalah 8,94, atau $F_{\text {hitung }}<F_{\text {tabel }}$, sehingga dapat disimpulkan bahwa data bersifat homogen. Uji homogenitas untuk kelompok siswa berkemampuan rendah, diperoleh nilai dari $F_{\text {tabel }}$ dengan taraf signifikasi 0,05 , derajat kebebasan pembilang 25 dan derajat kebebasan penyebut 17 adalah 2,19, atau $F_{\text {hitung }}<F_{\text {tabel }}$, sehingga dapat disimpulkan bahwa data bersifat homogen.

Data yang diperoleh tidak berdistribusi normal, maka digunakan statistik non parametrik yaitu uji Mann-Whitney atau U-tes untuk menguji hipotesis penelitian. Berdasarkan hasil anlisis data diperoleh nilai $\mathrm{p}$ untuk hipotesis pertama sebesar 0,0612 sehingga diperoleh $0,0612>0,05$ atau $\mathrm{p}>\alpha$, maka $\mathrm{H}_{0}$ diterima, artinya tidak ada perbedaan antara siswa yang belajar menggunakan model pembelajaran discovery learning dengan siswa yang belajar menggunakan model pembelajaran inquiry.

Nilai $\mathrm{p}$ untuk hipotesis kedua sebesar 0,4 sehingga diperoleh $0,4>0,05$ atau $\mathrm{p}>\alpha$ maka $\mathrm{H}_{0}$ diterima, artinya tidak ada perbedaan antara siswa berkemampuan tinggi yang belajar dengan model pembelajaran discovery learning dengan siswa berkemampuan tinggi yang belajar dengan model pembelajaran inquiry.

Nilai $\mathrm{p}$ untuk hipotesis ketiga sebesar 0,557 sehingga diperoleh 0,557 $>0,05$ atau $\mathrm{p}$ $>\alpha$ maka $\mathrm{H}_{0}$ diterima, artinya tidak ada perbedaan antara siswa berkemampuan sedang yang belajar dengan model pembelajaran discovery learning dengan siswa berkemampuan sedang yang belajar dengan model pembelajaran inquiry.

Nilai p untuk hipotesis keempat sebesar 0,9978 sehingga diperoleh 0,9978>0,05 atau $\mathrm{p}>\alpha$, maka $\mathrm{H}_{0}$ diterima, artinya tidak ada perbedaan antara siswa berkemampuan rendah yang belajar menggunakan model pembelajaran discovery learning dengan siswa berkemampuan rendah yang belajar menggunakan model pembelajaran inquiry.

\section{PEMBAHASAN}

Peneliti mengambil dua kelas secara acak untuk diberikan pre-test, yaitu kelas $\mathrm{X}$ MIA 3 dan X MIA 5. Peneliti kemudian menguji homogenitas pada kedua kelas ini berdasarkan pada data hasil pre-test dan diperoleh varians untuk kelas X MIA 3 sebesar 236,17 dan varians untuk kelas X MIA 5 sebesar 300,28. Diperoleh nilai $F_{\text {hitung }}$ sebesar 1,27 dan nilai $F_{\text {tabel }}$ sebesar 1,82, sehingga $F_{\text {hitung }}<F_{\text {tabel }}$ atau dapat disimpulkan bahwa kedua kelas homogen.

Peneliti memberikan perlakuan penerapan model pembelajaran discovery learning pada kelas X MIA 5 sebagai kelas eksperimen I dan penerapan model pembelajaran inquiry pada kelas X MIA 3 sebagai kelas eksperimen II. Penerapan kedua perlakuan ini dilakukan selama 3 pertemuan pada materi SPLTV, Relasi dan Fungsi. Penerapan model pembelajaran dilakukan oleh peneliti sendiri dengan pengamatan langsung oleh guru matematika. Siswa berhasil untuk menemukan sendiri konsep dari materi yang dipelajari 
dan dapat mengaplikasikannya dalam mengerjakan soal latihan yang diberikan. Hal ini menunjukan bahwa model pembelajaran inquiry dan discovery learning diterapkan dengan baik pada dua kelas eksperimen. Setelah melakukan penelitian, peneliti memberikan posttest kepada dua kelas eksperimen tersebut untuk memperoleh hasil belajar.

Butir soal post-test terlebih dahulu diujikan kepada kelas XI MIA 1 untuk menguji validitas dan reliabilitas butir soal menggunakan uji koefisien korelasi. Kelas ini dipilih karena telah mempelajari materi SPLTV, Relasi dan Fungsi. Setelah dilakukan perhitungan uji validitas, diperoleh nilai korelasi untuk soal nomor 1 sebesar 0,334 , nilai korelasi untuk soal nomor 2 sebesar 0,694, nilai korelasi untuk soal nomor 3 sebesar 0,887, nilai korelasi untuk soal nomor 4 sebesar 0,626, nilai korelasi untuk soal nomor 5 sebesar 0,484 dan nilai korelasi untuk soal nomor 6 sebesar 0,628. Hal ini menunjukan bahwa semua nilai korelasi di atas 0,3 sehingga dapat disimpulkan bahwa semua butir soal valid. Uji reliabilitas dengan menggunakan rumus Spearman Brown mengasilkan nilai korelasi sebesar 0,968 yang berarti bahwa butir soal reliabel.

Butir soal yang telah dinyatakan valid dan reliabel, selanjutnya diberikan kepada kedua kelas eksperimen sebagai post-test. Setelah post-test selesai diberikan, peneliti selanjutnya melakukan uji chi kuadrat untuk menguji normalitas data, hal ini dilakukan untuk menentukan uji statistik yang akan digunakan untuk menguji hipotesis penelitian. Sugiyono (2012:172) menyatakan bahwa penggunaan statistik parametris mensyaratkan bahwa data setiap variabel yang akan dianalisis harus berdistribusi normal.

Hasil yang diperoleh setelah melakukan perhitungan terhadap data $\chi_{\text {hitung }}^{2}$ sebesar 93,3 untuk kelas eksperimen I dan 130,85 untuk kelas eksperimen II, sedangkan nilai dari $\chi_{\text {tabel }}^{2}$ sebesar 7,81 atau $\chi_{\text {hitung }}^{2}>\chi_{\text {tabel }}^{2}$ sehingga dapat disimpulkan bahwa data tersebut tidak berdistribusi normal. Ketika data tidak berdistribusi normal, maka peneliti menggunakan statistik non parametris yaitu uji $U$ atau uji Mann Whitney untuk menganalisis data.

Hasil yang diperoleh setelah melakukan analisis data untuk menguji setiap hipotesis adalah bahwa nilai $\mathrm{p}>\alpha$ untuk semua hipotesis yang berarti tidak ada perbedaan yang signifikan terhadap hasil belajar siswa yang belajar menggunakan model pembelajaran discovery learning dan model pembelajaran inquiry, baik untuk siswa berkemampuan tinggi, sedang maupun rendah.

Kirschner dan Clark (2018:3) dalam artikelnya menjelaskan bahwa pembelajaran discovery learning dan inquiry hanya berbeda pada penamaan saja, tetapi secara esensi memiliki penerapan yang identik yang didalamnya terdapat langkah-langkah ilmiah sehingga siswa diposisikan dalam konteks pembelajaran penemuan dan diminta untuk menemukan sebuah konsep dengan cara membuat aktivitas investigasi seorang penemu.

Hasil yang diperoleh peneliti relevan dengan dengan hasil penelitian yang dilakukan oleh Sundari (2016), dimana hasil yang diperoleh Sundari adalah tidak terdapat pengaruh strategi discovery learning dan inquiry pada hasil belajar siswa. Sundari menyimpulkan bahwa strategi discovery learning dan inquiry tidak memberikan pengaruh terhadap hasil belajar siswa atau dapat dikatakan bahwa tidak ada perbedaan hasil belajar pada kelas yang belajar menggunakan strategi discovery learning dan inquiry.

\section{KESIMPULAN}

Setelah melakukan analisis data, dapat disimpulkan bahwa tidak ada perbedaan hasil belajar antara siswa yang belajar menggunakan model pembelajaran discovery learning 
dengan model pembelajaran inquiry. Hasil ini berlaku untuk keseluruhan kelas, kelompok siswa berkamampuan tinggi, sedang maupun rendah dari masing-masing kelas eksperimen.

\section{SARAN}

Saran yang diberikan peneliti yaitu dalam penerapan model pembelajaran discovery learning dan inquiry, guru dapat memilih materi geometri karena pada materi ini, konsep konsep geometri dapat diperoleh melalui eksperimen.

\section{DAFTAR PUSTAKA}

Hamiyah, N. Dan M. Jauhar. 2014. Strategi Belajar - Mengajar di Kelas. Jakarta: Prestasi Pustaka.

Hamruni. 2012. Strategi Pembelajaran. Yogyakarta: Insan Madani

Kosasih. 2013. Strategi Belajar Dan Pembelajaran. Bandung: Yrama Widya.

Kirschner, Paul \& Clark, Richard. 2018. Why Unguided Learning Does Not Work: An Analysis Of The Failure Of Discovery Learning, Problem-Based Learning, Experiental Learning And Inquiry-Based Learning. Open University of the Netherland [Online]. Tersedia: http://researchgate.net [2 Mei 2018].

Kurniasih, Imas dan Berlin Sani. 2014. Implementasi Kurikulum 2013 Konsep dan Penerapan. Surabaya: Kata Pena.

Maryam, Siti. 2016. Penerapan Model Pembelajaran Discovery Learning Dengan Menggunakan Struktur Konsep Pada Materi Persegi Panjang Dan Persegi Untuk Meningkatkan Hasil Belajar Siswa Di Kelas VII B MTs. Al-Khairat Tondo. Skripsi pada Universitas Tadulako Palu : tidak diterbitkan.

Palupi, Laela Lusi. 2013. Pengaruh Metode Inquiry Discovery Terhadap Hasil Belajar Matematika. Skripsi pada Universitas Sebelas Maret Surakarta [Online]. Tersedia: https://eprints.uns.ac.id/14070/1/2158-4923-1-PB.pdf. [12 Februari 2017 ].

Sugiyono. 2012. Metode Penelitian Kuantitatif Kualitatif Dan R\&D. Bandung: Alfabeta.

Sundari. 2016. Eksperimen Pembelajaran Matematika Dengan Strategi Discovery Learning Dan Inquiry Terhadap Hasil Belajar Ditinjau Dari Kemandirian Belajar Pada Siswa Kelas VII SMP Negeri 2 Tulung Tahun Ajaran 2015/2016. Skripsi pada Universitas Muhammadiyah Surakarta [Online]. Tersedia: repository.ums.ac.id/ 1327 [22 Januari 2018]. 